Journal of

Molecular Microbiology

and Biotechnology
J Mol Microbiol Biotechnol 2008;14:48-58

DOI: $\underline{10.1159 / 000106082}$

\title{
Lactococcus lactis, an Efficient Cell Factory for Recombinant Protein Production and Secretion
}

\author{
E. Morello ${ }^{a-c} \quad$ L.G. Bermúdez-Humarán ${ }^{b} \quad$ D. Llulld $\quad$ V. Soléc $\quad$ N. Miraglio ${ }^{c}$ \\ P. Langellab I. Poquet ${ }^{a}$
}

a Unité des Bactéries Lactiques et pathogènes Opportunistes (UBLO) et ${ }^{b}$ Unité d'Ecologie et de Physiologie du Système Digestif (UEPSD), INRA, Jouy-en-Josas, et ' ${ }^{\mathrm{GTP}}$ Technology, Prologue Biotech, rue Pierre et Marie Curie, Labège, France; ${ }^{d}$ Departamento de Microbiología Molecular, Centro de Investigaciones Biológicas, CSIC,

Madrid, Spain

\section{Key Words}

Lactococcus lactis - Recombinant protein - Expression

systems · Protein secretion · Production optimization using NICE or P170 expression systems under similar laboratory conditions. Finally, the toolbox we are developing should contribute to enlarge the use of L. lactis as a protein cell factory.

Copyright $\odot 2008$ S. Karger AG, Base

\begin{abstract}
The use of Gram-positive bacteria for heterologous protein production proves to be a useful choice due to easy protein secretion and purification. The lactic acid bacterium Lactococcus lactis emerges as an attractive alternative to the Grampositive model Bacillus subtilis. Here, we review recent work on the expression and secretion systems available for heterologous protein secretion in L. lactis, including promoters, signal peptides and mutant host strains known to overcome some bottlenecks of the process. Among the tools developed in our laboratory, inactivation of $\mathrm{HtrA}$, the unique housekeeping protease at the cell surface, or complementation of the Sec machinery with $B$. subtilis SecDF accessory protein each result in the increase in heterologous protein yield. Furthermore, our lactococcal expression/secretion system, using both $\mathrm{P}_{\mathrm{Zn}}$ zitR, an expression cassette tightly controlled by environmental zinc, and a consensus signal peptide, $\mathrm{SP}_{\text {Exp4}}$, allows efficient production and secretion of the staphylococcal nuclease, as evidenced by protein yields (protein amount/biomass) comparable to those obtained
\end{abstract}

\section{Introduction}

To date, many expression systems have been developed to produce recombinant proteins for various biotechnological applications. Among prokaryotic systems, the highest protein levels are obtained using Escherichia coli as the cell factory [Jana et al., 2005]. However, in E. coli, the most commonly used production strategies are intracellular (in the periplasm or even in the cytoplasm), and involve expensive and often problematic downstream purification processes. Moreover, endotoxin or lipopolysaccharide should be removed from proteins to be administered to humans.

In contrast, heterologous proteins produced in Grampositive bacterial hosts can be easily secreted into the medium, thus facilitating their purification. Bacillus species have been widely used to produce enzymes, even though most of them are homologous and naturally-secreted

\section{KARGER}

Fax +41613061234

E-Mail karger@karger.ch

www.karger.com
(C) 2008 S. Karger AG, Basel

$1464-1801 / 08 / 0143-0048 \$ 24.50 / 0$

Accessible online at:

www.karger.com $/ \mathrm{mmb}$
I. Poquet

Unité des Bactéries Lactiques et pathogènes Opportunistes (UBLO), INRA

FR-78352 Jouy-en-Josas Cedex (France)

Tel. +33 1346524 66, Fax +33 134652065

E-Mail isabelle.poquet@jouy.inra.fr 
proteins, like alkaline proteases used in washing agents or amylases for the starch industry [for review, see Westers et al., 2004]. Bacillus subtilis is endotoxin free and considered as a 'generally recognized as safe' micro-organism [Li et al., 2004]. However, many heterologous proteins secreted by $B$. subtilis are degraded by its complex extracellular proteolytic system, comprising 7 secreted and 5 cell surface proteases [for review, see Westers et al., 2004]. Mutant strains defective for several extracellular proteases have been constructed; in particular, WB800 is devoid of all 7 secreted proteases and the cell surface protease WprA [Wu et al., 2002]. Extracellular proteolysis is thus only limited without being abolished, as HtrA and CtpA family members are still present.

Another Gram-positive bacterium having a 'generally recognized as safe' status, the lactic acid bacterium model Lactococcus lactis, is becoming an attractive alternative for heterologous protein secretion. L. lactis has been studied for the last 2 decades: its metabolism is relatively simple and well known, and the genome of the IL1403 laboratory strain is sequenced [Bolotin et al., 2001]. L. lactis presents similar putative bottlenecks in protein production and secretion as B. subtilis (fig. 1), but it also provides several advantages. Only 1 major protein, Usp45, is secreted into the medium (at a level detectable by Coomassie brilliant blue staining) [van Asseldonk et al., 1993], thus simplifying downstream purification processes. Laboratory strains possess only 1 exported housekeeping protease, HtrA, and an extracellular protease-free mutant is available [Poquet et al., 2000, 2001]. Finally, although the ways to reach a high biomass level will not be discussed here [Riesenberg and Guthke, 1999], L. lactis growth under fermentation conditions allows an easy scale-up [Mierau et al., 2005a].

Here, we first review the tools that have been developed and used to produce and secrete heterologous proteins in L. lactis before describing our recent advances in putting together an innovative toolbox.

\section{Gene Expression Systems}

A lot of expression systems have been described in L. lactis [for reviews, see de Vos, 1997, 1999]. In the following section, we focus on either constitutive or inducible promoters that have been used for heterologous gene expression in L. lactis.

\section{Constitutive Promoters}

In L. lactis, numerous identified promoters are not known to be controlled by any regulator or growth conditions, and are presumed to be constitutive under labo- ratory growth conditions. The most commonly used promoters were randomly isolated from an L. lactis genomic library as fusions to the promoterless cat-86 reporter gene conferring chloramphenicol resistance [van der Vossen et al., 1987]. Five promoters - P21, P23, P32, P44 and P59 - were obtained as active transcriptional fusions in both L. lactis and B. subtilis. Strong (P21, P23 and P59) and weak (P32 and $\mathrm{P} 44$ ) promoters were distinguished by the chloramphenicol acetyl transferase activity levels, and the sequences of the strongest promoters were found to best fit with the consensus [van der Vossen et al., 1987]. These promoters have been used to produce numerous heterologous proteins in L. lactis (table 1).

\section{Inducible Promoters}

Inducible promoters generally drive the expression of genes involved in cell adaptation to its environment. Many L. lactis promoters are known to be inducible either by stress conditions such as phage attack, temperature or $\mathrm{pH}$ shift, or by a specific sugar [for reviews, see de Vos, 1997, 1999; for a recent example, see Miyoshi et al., 2004]. Regulated promoters are of particular interest in the case of putatively toxic genes whose repression should allow biomass increase prior to induction at a defined culture phase/time to produce the desired proteins.

The nisin-inducible controlled gene expression (NICE) system [de Ruyter et al., 1996; for reviews, see Kuipers et al., 1995, 1997, 1998] derives from the nis (nisABTCIPRKE$F G$ ) operon present in some L. lactis strains, which is involved in the biosynthesis of the antimicrobial peptide nisin [Kuipers et al., 1998]. NICE comprises the regulatory elements of the nis operon: $\mathrm{P}_{\text {nisA }}$, the nisin-inducible promoter (cloned into several expression vectors), and $n i s R K$, the regulator-sensor 2-component system (either carried by compatible plasmids or integrated in the chromosome). The NICE system has been extensively used to produce proteins in L. lactis [for reviews, see Kunji et al., 2003; Le Loir et al., 2005; Mierau and Kleerebezem, 2005]. It offers numerous advantages: (1) easy use, (2) tightly controlled and efficiently induced expression leading to high protein yields [Mierau and Kleerebezem, 2005], and (3) large-scale production process, as recently shown for Staphylococcus simulans lysostaphin [Mierau et al., 2005a, b]. Growth conditions, fermentation parameters and nisin amounts have been optimized, leading to a lysostaphin yield increase from 100 to $300 \mathrm{mg} / \mathrm{l}$ [Mierau et al., 2005b]. The process is equally effective for production scales of 1, 300 or even 3,000 liters, without any loss of productivity [Mierau et al., 2005a, b]. However, for industrial production, nisin addition remains costly and, in the 


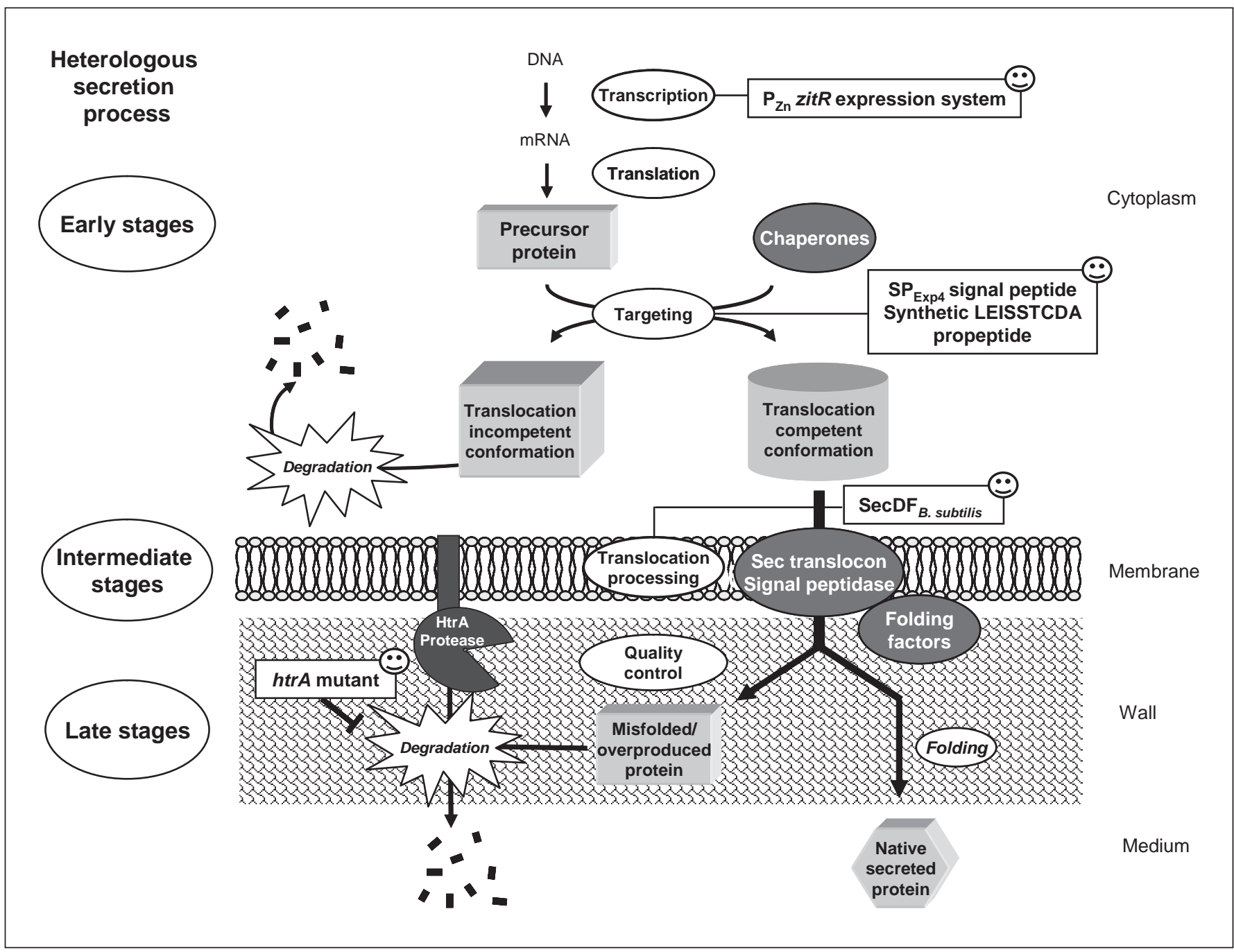

Fig. 1. Heterologous protein secretion in L. lactis. In L. lactis, as in $B$. subtilis, the heterologous secretion [for reviews, see Li et al., 2004 and Westers et al., 2004] can be divided into 3 stages: (1) early secretion steps in the cytoplasm, which include precursor synthesis and targeting to the translocation machinery, (2) intermediate secretion steps that allow translocation of the precursor across the membrane (through the Sec translocon) and signal peptide cleavage, and (3) late secretion stages corresponding to protein quality control, which comprise the degradation of overproduced or misfolded proteins and the folding of mature protein and its release into the medium. The tools reported here are marked by the following icon: $:$. particular case of a protein of pharmaceutical interest, a downstream removal process should be required.

The P170 gene expression system [Israelsen et al., 1995; Madsen et al., 1999] has also been reported to be compatible with industrial production and fermentation processes in L. lactis. P170, the natural promoter of an uncharacterized gene termed orf $\mathrm{X}$, is induced by the $\mathrm{pH}$ decrease $(\mathrm{pH}<6)$ during transition from postexponential to stationary phases of glucose-grown cultures [Bredmose et al., 2001; Madsen et al., 1999]. P170 induction depends on $\mathrm{RcfB}$, a positive regulator of the CRP-FNR family which binds on ACiD-boxes [Madsen et al., 2005]. For protein production, P170 offers the major advantage (compared to the NICE system) of self-inducibility via lactic acid accumulation in the medium during growth. Using P170, the staphylococcal nuclease (Nuc) yield reaches $300 \mathrm{mg} / \mathrm{l}$. Scale-up experiments from 1 to $200 \mathrm{li}$ ters in 1 step have been achieved leading to similar protein yield, purity and stability (Bioneer; http://www.lactococcus.dk/). 
Table 1. Heterologous proteins produced in L. lactis under the control of constitutive promoters

\begin{tabular}{|c|c|c|c|c|}
\hline Protein & Origin & Promoter & Strain & Reference \\
\hline Chitinase & Serratia marcescens & P32, P59 & MG1363 & Brurberg et al., 1994 \\
\hline M6 & Streptococcus pyogenes & P23, P59 & IL1403 & Piard et al., 1997 \\
\hline $\mathrm{SlpH}$ & Lactobacillus helveticus & P32 & MG1363 & Callegari et al., 1998 \\
\hline Phenylalanine ammonia-lyase & Petroselinum crispum & P32 & MG1363 & Xiang et al., 1999 \\
\hline Carnobacteriocin A & Carnobacterium piscicola & P32 & MG1363 & Franz et al., 2000 \\
\hline FnBPA & S. aureus & P23 & MG1363 & Que et al., 2001 \\
\hline Nuc & S. aureus & P59 & MG1363 & Dieye et al., 2001 \\
\hline VP2, VP3 & Infectious bursal disease virus & P59 & MG1363 & Dieye et al., 2003 \\
\hline $\mathrm{Cu} / \mathrm{Zn}$ superoxide dismutase & Homo sapiens & P32 & MG5267 & Wei et al., 2003 \\
\hline Enterocin A & Enterococcus faecium & P32 & IL1403 & Martinez et al., 2000 \\
\hline Pediocin PA-1 & Pediococcus acidilactici & & & \\
\hline
\end{tabular}

A new expression system in L. lactis, $\mathrm{P}_{\mathrm{Zn}}$ zitR, has recently been developed. It naturally controls expression of the zit operon (zitRSQP). By homology with streptococcal adc operons, zit is putatively involved in $\mathrm{Zn}^{2+}$ uptake by the ABC transporter ZitSQP, and it is controlled by ZitR, an MarR family transcriptional regulator [Llull and Poquet, 2004; Llull et al., in preparation]. An expression vector including $\mathrm{P}_{\mathrm{Zn}}$ zitR promoter-regulator region, pVE8062, was constructed [Llull and Poquet, 2004]. Using 2 reporter proteins, a secreted recombinant Nuc $\left(\mathrm{SP}_{\mathrm{Usp} 45}-\mathrm{Nuc}\right)$ or a cytoplasmic $\beta$-galactosidase, Leuconostoc mesenteroides LacLM, $\mathrm{P}_{\mathrm{Zn}}$ zitR-controlled expression proved to be tightly regulated in response to zinc concentration in the medium [Llull and Poquet, 2004]. Furthermore, $\mathrm{P}_{\mathrm{Zn}} z i t R$ has been compared to NICE using the above-mentioned reporter genes (cloned in the same contexts), and expressed in each case under defined induction conditions (EDTA $30 \mu \mathrm{M}$ or nisin $1 \mathrm{ng} / \mathrm{ml}$ in chemically defined SA medium) [Jensen et al., 1993]. After $3 \mathrm{~h}$ of induction, $\mathrm{P}_{n i s A}$ gave a 5 -fold higher level of LacLM activity than $\mathrm{P}_{\mathrm{Zn}}$, but Western blotting showed a similar Nuc protein yield for both systems [Llull and Poquet, 2004].

We propose the following model for the regulation of either $z i t$ or any heterologous gene cloned under $\mathrm{P}_{\mathrm{Zn}} z i t R$ control [Llull and Poquet, 2004; Llull et al., in preparation]. Under zinc excess in the medium (in a large range of concentrations), ZitR bound to $\mathrm{P}_{\mathrm{Zn}}$ represses expression by competing with RNA polymerase binding (fig. 2a). Alternatively, under extreme $\mathrm{Zn}^{2+}$ starvation that can be achieved either through EDTA addition or growth in a zinc-poor medium (like SA medium), ZitR becomes inactive and allows RNA polymerase binding to $\mathrm{P}_{\mathrm{Zn}}$ and transcription initiation (fig. 2b). The $\mathrm{P}_{\mathrm{Zn}} z i t R$ system thus appears well suited for heterologous expression control. If heterologous protein toxicity is a risk, zinc addition should allow repression and biomass increase before induction by EDTA at the late exponential growth phase (note that EDTA is both food grade and present in the suspension buffers of several injectable therapeutic products including proteins; http://www.fda.gov/cder/biologics). Alternatively, if moderate heterologous protein levels can be tolerated during the exponential phase, the use of a zinc-poor medium should allow a progressive self-induction without any additions [Llull and Poquet, 2004; Poquet and Llull, 2006]. This production process is of particular interest because it is cheap and compatible with large-scale production.

\section{Protein Secretion in L. lactis}

L. lactis is able to secrete proteins bearing an N-terminal signal peptide into the growth medium via the Sec pathway (fig. 1). Early secretion stages involve protein precursor recognition and targeting to the membrane translocation machinery, which are assumed to be cotranslational via the dedicated chaperone signal recognition particle. During translocation, the precursor protein crosses the membrane through the Sec translocon. Late secretion steps include signal peptide cleavage by the leader peptidase, mature protein release and folding. In 


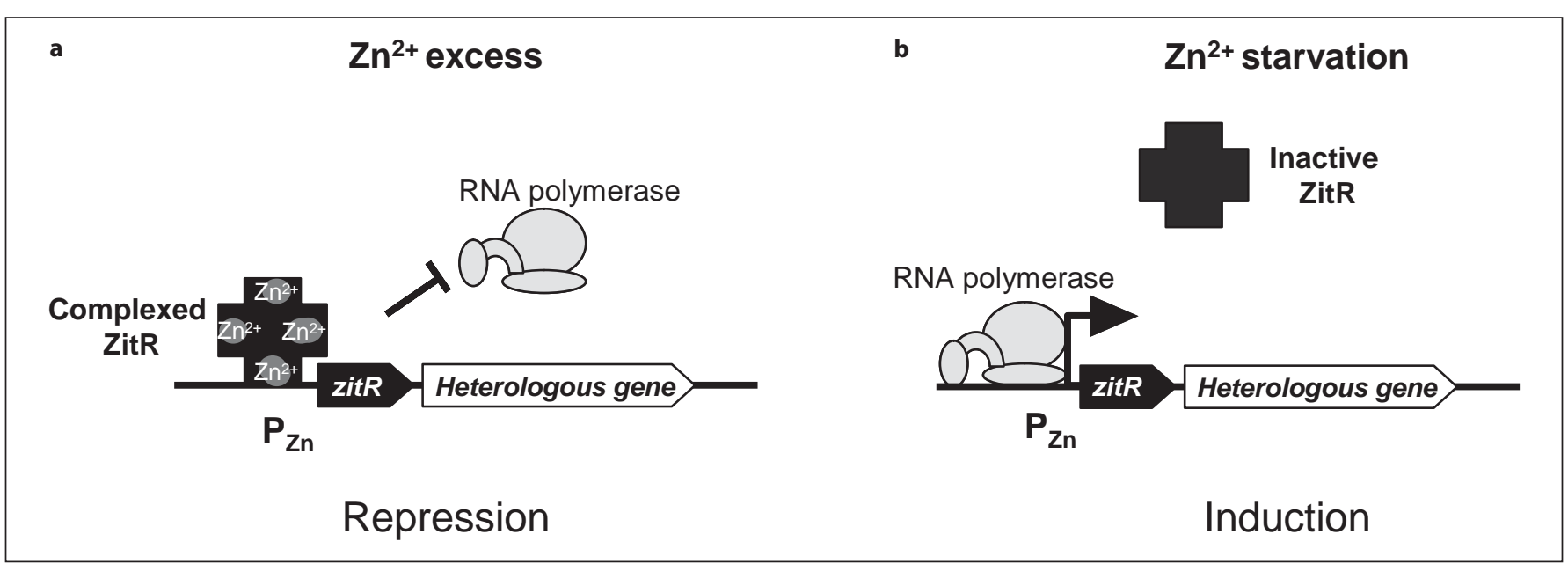

Fig. 2. Model for $\mathrm{P}_{\mathrm{Zn}}$ zitR regulation of heterologous protein expression. Under extracellular zinc excess conditions (a), ZitR repressor binds $\mathrm{P}_{\mathrm{Zn}}$ promoter region and prevents transcription initiation by RNA polymerase, whereas zinc starvation conditions (b), obtained either by EDTA chelator addition or by growth in zinc-poor medium, allow transcriptional switch-on and induced expression.

the following section, we present the export signals used to drive heterologous secretion in L. lactis, and L. lactis mutant strains that can improve this process.

Addressing Targeted Proteins to the Sec Pathway

L. lactis signal peptides have been identified and characterized either randomly or studying specific exported proteins. L. lactis naturally secretes only 1 major protein, Usp45, possibly involved in cell wall hydrolysis and cellular segregation (as deduced by homology) [van Asseldonk et al., 1993]. Usp45 signal peptide $\left(\mathrm{SP}_{\mathrm{Usp} 45}\right)$ is commonly used for heterologous protein secretion in L. lactis. $\mathrm{SP}_{\mathrm{Usp} 45}$ has been combined with either a constitutive promoter like P59 [Dieye et al., 2001] or the inducible NICE system [for review, see Bermudez-Humaran et al., 2003a, b; Le Loir et al., 2005; Mierau et al., 2005b; Novotny et al., 2005]. Other signal peptides were identified in screens as reporter fusions, either alone [Perez-Martinez et al., 1992] or as combined expression and secretion cassettes [Poquet et al., 1998; Ravn et al., 2000; Sibakov et al., 1991]. One of them, SP310, was optimized by site-directed mutagenesis [Ravn et al., 2003]. Our library of signal peptides [Poquet et al., 1998] included $\mathrm{SP}_{\mathrm{Exp} 4}$, whose structure and amino acid composition best fit with the Grampositive consensus [Poquet and Llull, 2006]. $\mathrm{SP}_{\text {Exp4 }}$ proved to efficiently drive secretion of the murine IL-12 p40 subunit in L. lactis [Bermudez-Humaran et al., 2003b].

A short synthetic propeptide (LEISSTCDA) can be fused between a signal peptide and the mature part of the protein to improve the efficiency of heterologous secretion in L. lactis, as shown for several proteins (Nuc, Brucella abortus L7/L12 antigen or Bacillus stearothermophilus $\alpha$-amylase) [Le Loir et al., 1998, 2001, 2005]. The LEISSTCDA effect was observed in different contexts, using different proteins and signal peptides (both $\mathrm{SP}_{\mathrm{Nuc}}$ signal peptide [Le Loir et al., 1998] and lactococcal $\mathrm{SP}_{\mathrm{Usp} 45}$ [Le Loir et al., 2001] have been used in the case of Nuc). It is likely that the negatively charged residues of the propeptide optimize the charge balance around the transmembrane domain of the signal peptide and thus enhance its efficiency and protein translocation [Le Loir et al., 1998, 2001]. LEISSTCDA fusion leads to an overall increase in protein yield, suggesting an indirect effect on intracellular proteolysis of the precursor [Le Loir et al., 2005].

Host Factors Affecting Secretion and/or Production of Heterologous Proteins

Secretion in Gram-positive bacteria is a multistep process, and factors localized in all cell compartments might become limiting in the case of overproduced heterologous proteins (fig. 1). A secretion stress was described in B. subtilis as a result of overproduction of a heterologous secreted protein, leading in turn to a global regulatory response including genes involved in stress resistance and secretion [Hyyryläinen et al., 2005]. In L. lactis, secretion factors have essentially been identified by homology with $E$. coli and B. subtilis. Here, we describe studies aimed at improving heterologous secretion, essentially by overproducing 
limiting factors or inactivating adverse ones. Random mutagenesis has also been performed for this purpose [Nouaille et al., 2004; Morello et al., submitted].

Intracellular Targeting Factors. Bacterial ffh genes encode the protein component of signal recognition particle and are involved in protein secretion and folding [Tjalsma et al., 2004]. In B. subtilis, ffh is induced as part of the response to a severe secretion stress [Hyyryläinen et al., 2005]. Our attempts to overproduce L. lactisffh in strains producing an inefficiently secreted Nuc form failed to increase its yield [Morello et al., unpubl. data].

Translocation Machinery. L. lactis translocon includes (1) SecA, the ATPase-dependent motor, which partially provides the energy required for preprotein translocation, and (2) SecY, SecE and SecG integral membrane proteins, which form the conducting channel through the hydrophobic membrane environment. The lactococcal Sec machinery is simpler than those of B. subtilis or E. coli, as the SecDF accessory component (either both E. coli SecD and SecF proteins or B. subtilis SecDF Siamese twin protein) is missing. B. subtilis SecDF enhances protein translocation by an as yet unknown mechanism [Bolhuis et al., 1998 and references therein]. Its expression in L. lactis results in increased yield of an inefficiently secreted Nuc form and of a B. abortus L7/L12 antigen, possibly by an indirect stabilization effect during translocation [Nouaille et al., 2006].

Signal Peptide Cleavage. During or shortly after preprotein translocation across the membrane, the signal peptide is removed by type I signal peptidase, releasing the mature form. In B. subtilis or Bacillus megaterium, processing relies on several signal peptidases and represents a bottleneck for some heterologous secreted proteins [Bolhuis et al., 1999; Malten et al., 2005]. In L. lactis, there is a unique type I signal peptidase, SipL. SipL overproduction in an L. lactis strain producing the inefficiently secreted Nuc form did not improve its secretion [Morello et al., unpubl. data].

Surface Quality Control Proteins. Proteins that are transported through the Sec machinery are unfolded. When they emerge from the membrane, proper folding into their native conformation is ensured by a protein quality control network involving (1) folding factors like chaperones and folding catalysts, and (2) housekeeping proteases to degrade misfolded/unfolded proteins [for Gram-positive bacteria, see review by Sarvas et al., 2004]. L. lactis quality control factors affect heterologous protein secretion.

L. lactis PmpA is a lipoprotein belonging to the peptidyl-prolyl-cis/trans-isomerase family. This protein is ho-

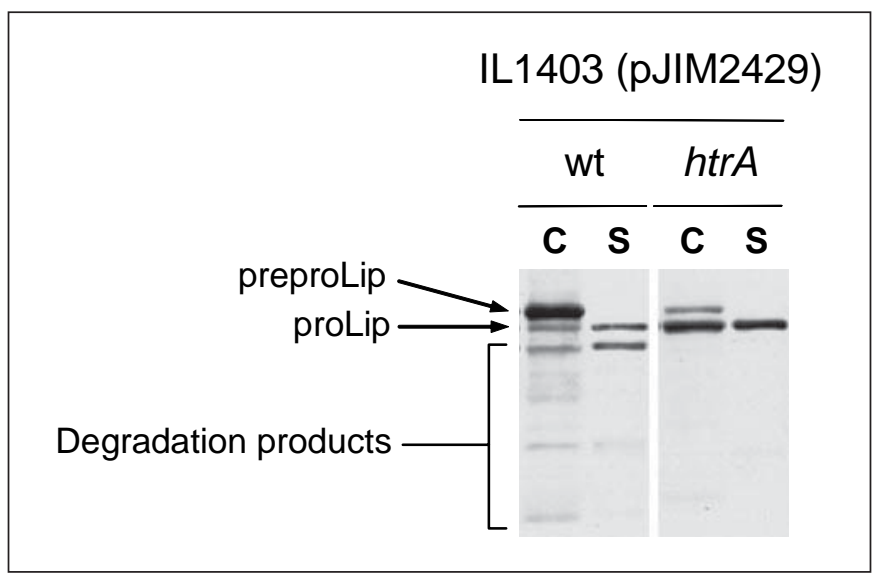

Fig. 3. S. hyicus-secreted lipase (Lip) is stable in an L. lactis htrA mutant strain. Lip secretion is compared in IL1403 wild-type (wt) and $h$ trA mutant strains carrying the pJIM2429 expression vector (P23 lip) [Drouault et al., 2000]. IL1403 (pJIM2429) and IL1403htrA (pJIM2429) strains were grown exponentially at $30^{\circ} \mathrm{C}$ and proteins from cells $(\mathrm{C})$ or supernatant $(\mathrm{S})$ fractions were analyzed after SDS-PAGE by Western blotting using antibodies against the Lip C-terminus. Precursor (preproLip) and mature form (proLip) after signal peptide processing and degradation products are shown.

mologous to B. subtilis PrsA, a general surface folding factor whose overproduction is known to improve heterologous protein secretion [Kontinen et al., 1991, 1993]. L. lactis PmpA has been proposed to be a surface chaperone [Drouault et al., 2002]. When Lip, the secreted lipase of Staphylococcus hyicus, is produced in L. lactis, it is highly degraded, but this degradation can be inhibited by PmpA overproduction [Drouault et al., 2002]. This study showed that extracellular folding of heterologous proteins like Lip can be inefficient in L. lactis, and that PmpA overproduction can overcome this problem.

In L. lactis, HtrA is the unique exported housekeeping protease involved in protein quality control at the cell surface [Poquet et al., 2000]. HtrA is responsible for clearing abnormal proteins, such as reporter fusions, from the surface, and is both essential and induced under several stress conditions [Foucaud-Scheunemann and Poquet, 2003; Poquet et al., 2000]. htrA inactivation abolished the degradation of heterologous exported proteins, like Lip, allowing a 4-fold yield increase (fig. 3) [Miyoshi et al., 2002; Poquet et al., 2000, 2006]. All tested proteins are entirely stable in $h t r A$ mutant, suggesting that this mutant is protease-free at the cell surface [Poquet et al., 2000, $2001,2006]$, a major advantage for developing L. lactis as a cell factory for protein production and secretion. 
Table 2. Toolbox for protein production and secretion in L. lactis

\begin{tabular}{|c|c|c|}
\hline Name & Characteristics & Reference \\
\hline \multicolumn{3}{|c|}{ Lactococcal mutant strains } \\
\hline IL1403 htrA & $\begin{array}{l}\text { htrA mutant of IL1403 strain } \\
\text { htrA inactivated by single crossing-over recombination, } \mathrm{Cm}^{\mathrm{R}}\end{array}$ & Poquet et al., 2000 \\
\hline NZ9000 htrA & $\begin{array}{l}\text { htrA mutant of NZ9000 (MG1363::nisRK) strain } \\
\text { htrA inactivated by single crossing-over recombination, } \text { Erm }^{\mathrm{R}}\end{array}$ & Miyoshi et al., 2002 \\
\hline MG1363 $\Delta h t r A$ & $\begin{array}{l}\text { htrA mutant of MG1363 } \\
h t r A \text { inactivated by internal deletion (by the same strategy used for NZ9000 } \Delta h t r A \text { ) }\end{array}$ & $\begin{array}{l}\text { Madsen et al., } \\
\text { unpubl. data }\end{array}$ \\
\hline NZ9000 SecDF & $\mathrm{NZ9000}(\mathrm{pSecDFl})$ & Nouaille et al., 2006 \\
\hline $\begin{array}{l}\text { Plasmids } \\
\text { pSecDFl }\end{array}$ & $\begin{array}{l}\text { pAM } \beta 1 / \text { ColE1; } \operatorname{Erm}^{\mathrm{R}}, \mathrm{Amp}^{\mathrm{R}} ; \sec \mathrm{DF} F_{\mathrm{B} \text {. subtilis }} \text { encoding wild-type B. subtilis } \\
\text { SecDF protein }\end{array}$ & Nouaille et al., 2006 \\
\hline
\end{tabular}

A New Expression/Secretion System for Heterologous

Proteins in L. lactis

To improve heterologous protein secretion in L. lactis (fig. 1), we are developing an innovative toolbox comprising a set of mutant strains and an integrated expression and secretion system (table 2).

Strains

The L. lactis htrA mutant strain proved to efficiently stabilize heterologous secreted proteins [Miyoshi et al., 2002; Poquet et al., 2000, 2006]. Several different $h t r A$ mutant strains are available and have been constructed in different genetic backgrounds and by different strategies (table 2).

An alternative strategy to improve the secretion process is to overproduce an enhancing factor. A genome comparison approach led to the complementation of L. lactis Sec translocon by B. subtilis SecDF (cloned in pSecDF1 plasmid; table 2), leading to an increase in protein yield [Nouaille et al., 2006].

\section{Towards a New Expression/Secretion System}

A new expression and secretion system was recently developed by combining the $\mathrm{P}_{\mathrm{Zn}}$ zitR expression system, the $\mathrm{SP}_{\text {Exp } 4}$ signal peptide and the htrA mutant strain.

$P_{Z n}$ zitR-Driven Heterologous Expression. Efficiency of the $\mathrm{P}_{\mathrm{Zn}} z i t R$ expression system was evaluated in the $h t r A$ mutant strain context, using a recombinant Nuc form
$\left(\mathrm{SP}_{\mathrm{Usp} 45}-\mathrm{Nuc}\right)$ as a heterologous reporter. Northern blotting (fig. 4) of extracts from the MG1363 $\Delta h t r A$ (pVE8064) strain (table 2) grown in SA medium shows a basal expression level of the reporter during early exponential growth $\left(\mathrm{OD}_{600}=0.1\right.$ or $\mathrm{T}_{0}$; fig. 4). Levels increase in the course of growth (data not shown) as a result of $\mathrm{P}_{\mathrm{Zn}}$ selfinduction in SA medium [Llull and Poquet, 2004; Poquet and Llull, 2006]. Successful induction or repression can be achieved in an $h t r A$ mutant strain under the same conditions as in a wild-type strain [Llull and Poquet, 2004]: addition at $\mathrm{T}_{0}$ of $30 \mu \mathrm{M}$ EDTA or $10 \mu \mathrm{M} \mathrm{ZnSO}$ leads to an increase in expression greater than 150 -fold, or to a complete expression switch-off after either 0.5 or $1 \mathrm{~h}$ of the respective treatments (fig. $4 \mathrm{~b}$ ). These results show that the tight control of $\mathrm{P}_{\mathrm{Zn}}$ zitR-driven expression is functional in an $h$ trA strain context.

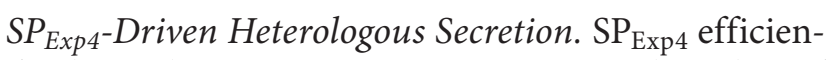
cy for heterologous secretion was compared to that of $\mathrm{SP}_{\mathrm{Usp45}}$ as a reference, using Nuc as a reporter $\left(\mathrm{SP}_{\mathrm{Exp} 4}{ }^{-}\right.$ Nuc and $\mathrm{SP}_{\mathrm{Usp} 45}-\mathrm{Nuc}$ recombinant proteins were cloned into the same expression vector; fig. 5a). Western blot analysis reveals the same production and secretion profiles, no matter what signal peptide was used (fig. 5b). This result shows that $\mathrm{SP}_{\mathrm{Exp} 4}$ and $\mathrm{SP}_{\mathrm{Usp} 45}$ are equally effective for Nuc secretion. $\mathrm{SP}_{\operatorname{Exp} 4}$ thus represents an interesting alternative for efficient heterologous protein secretion in L. lactis. 
Fig. 4. Efficiency of $\mathrm{P}_{\mathrm{Zn}}$ zitR expression system in an L. lactis htrA mutant strain. a Heterologous expression and secretion cassette from pVE8064 [Llull and Poquet, 2004]. In pVE8064, a recombinant Nuc form, $\mathrm{SP}_{\mathrm{Usp} 45}$-Nuc (encoded by $u s p_{S P}-n u c$ fusion) is produced under $\mathrm{P}_{\mathrm{Zn}}$ zitR control. b Northern blot analysis. MG1363 $\Delta h t r A$ (pVE8064) strain was grown in chemically defined SA medium at $30^{\circ} \mathrm{C}$ until $\mathrm{OD}_{600}=0.1\left(\mathrm{~T}_{0}\right)$. At $\mathrm{T}_{0}$, cultures were divided into 2 subcultures. $\mathrm{ZnSO}_{4}$ or EDTA was added at final concentrations of 10 or $30 \mu \mathrm{M}$, respectively. Sample cultures were taken at $\mathrm{T}_{0}+0.5 \mathrm{~h}$ or $\mathrm{T}_{0}+1 \mathrm{~h}$; after RNA extraction, $u s p_{S P}-n u c$ mRNA was revealed by a ${ }^{32} \mathrm{P}$-labelled nuc probe.

Fig. 5. Secretion efficiency of $\mathrm{SP}_{\operatorname{Exp} 4}$ compared to that of $\mathrm{SP}_{\mathrm{Usp} 45}$. a Heterologous expression and secretion cassettes of pSec:Nuc and pLB141. In pSec:Nuc (also called pSEC1) [Le Loir et al., 1998] and pLB141 (constructed from pSec:p35-p40 [Bermudez-Humaran et al., 2003b], and thus containing the same backbone vector as pSec:Nuc), 2 recombinant Nuc forms, $\mathrm{SP}_{\mathrm{Usp} 45}-\mathrm{Nuc}$ and $\mathrm{SP}_{\mathrm{Exp} 4}{ }^{-}$ Nuc (encoded by $u s p_{S P}-n u c$ and $\exp 4_{S P}-n u c$ fusions, respectively) are produced under NICE control. b Western blot analysis. NZ9000 (pSec:Nuc) and NZ9000 (pLB141) strains were grown exponentially to $\mathrm{OD}_{600}=0.4$ and $1 \mathrm{ng} / \mathrm{ml}$ nisin was added for $1 \mathrm{~h}$. Proteins from cells $(\mathrm{C})$ and supernatant $(\mathrm{S})$ fractions were analyzed by SDS-PAGE and Western blotting using anti-Nuc antibodies. Precursor forms $\left(\mathrm{SP}_{\mathrm{Usp} 45}-\mathrm{Nuc}\right.$ and $\mathrm{SP}_{\text {Exp4 }}$-Nuc, both referred to as pre.), primary mature and secreted forms (resulting from $\mathrm{SP}_{\mathrm{Usp} 45}$ or $\mathrm{SP}_{\mathrm{Exp} 4}$ processing, both referred to as $\mathrm{NucB}$ ) and secondary mature forms (resulting from HtrA processing, referred to as NucA) are shown.

A New Expression/Secretion System. $\mathrm{P}_{\mathrm{Zn}}$ zitR expression system and $\mathrm{SP}_{\mathrm{Exp} 4}$ signal peptide have been cloned together, leading to a new expression/secretion vector. pLB145 was used to produce and secrete a recombinant

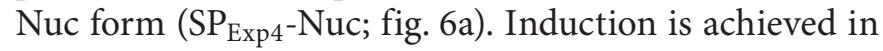
IL1403 (pLB145) strain grown in GM17 medium at $30^{\circ} \mathrm{C}$ by addition of $1 \mathrm{~mm}$ EDTA at $\mathrm{OD}_{600}=0.1$. Coomassie staining shows that recombinant Nuc secretion into the medium is efficient as amounts of Nuc forms exceed those of Usp45: Nuc yield in the medium reaches $10 \mathrm{mg} /$ $1 / \mathrm{OD}_{600}$ after $4 \mathrm{~h}$ of induction (fig. $6 \mathrm{~b}$ ). This is close to yields previously reported for $\mathrm{SP}_{\mathrm{Usp} 45}-\mathrm{Nuc}$ fusion using a

pVE8064

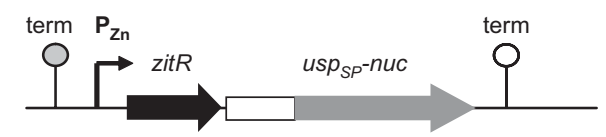

b

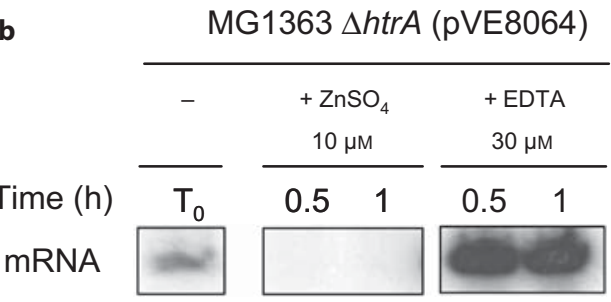

a

pSec:Nuc

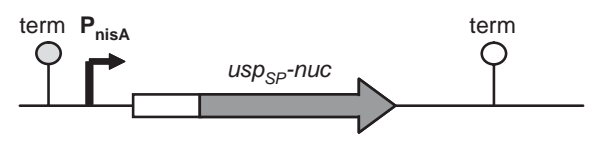

pLB141

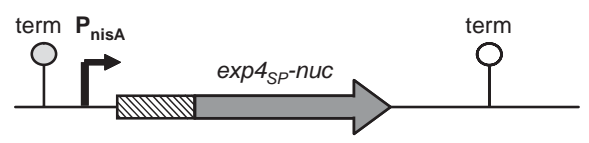

b NZ9000

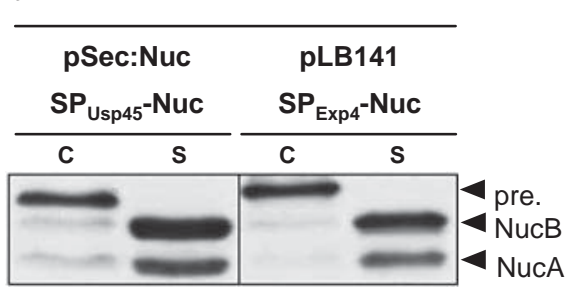

either the NICE system $\left(20 \mathrm{mg} / \mathrm{l} / \mathrm{OD}_{600}\right.$ after induction by $1 \mathrm{ng} / \mathrm{ml}$ nisin) [Bermudez-Humaran et al., 2003a] or the P170 system $\left(5 \mathrm{mg} / \mathrm{l}_{\mathrm{OOD}} \mathrm{OD}_{60}\right.$ at $\left.\mathrm{pH}=5.2\right)$ [Madsen et al., 2000] under similar conditions (in GM17 medium), even though optimized fermentation processes and possibly chemically defined medium could greatly improve yields [Mierau et al., 2005b; Ravn et al., 2000]. The $\mathrm{P}_{\mathrm{Zn}}$ $z i t R \mathrm{SP}_{\mathrm{Exp} 4}$ expression/secretion system is thus a new effective tool to produce and secrete heterologous proteins in L. lactis, either in a wild-type (fig. 6b) or an htrA mutant strain (data not shown). 


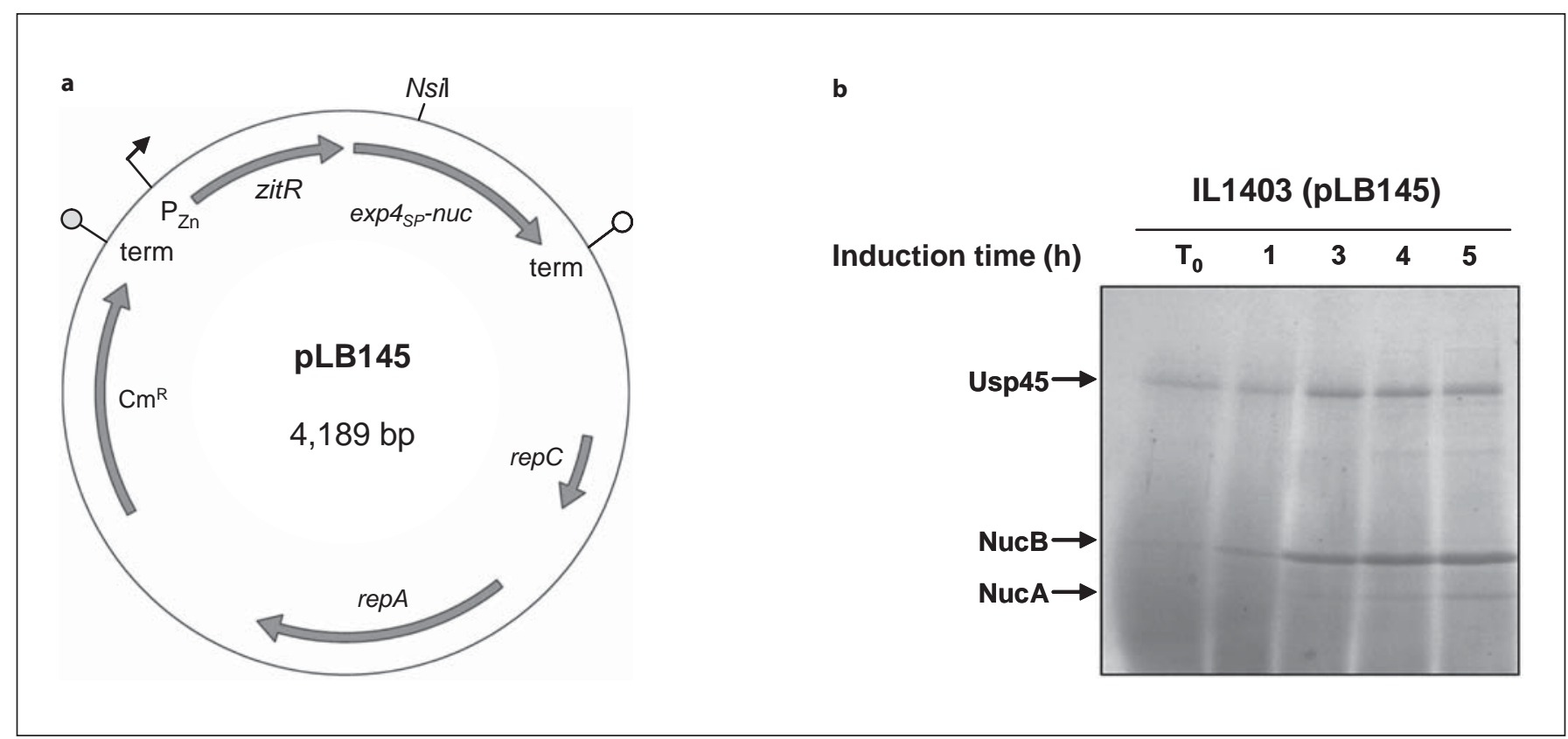

Fig. 6. Staphylococcal nuclease production using the $\mathrm{P}_{\mathrm{Zn}}$ zitR $\mathrm{SP}_{\text {Exp4 }}$ expression/secretion system. a pLB145 expression/secretion vector. $\mathrm{pLB} 145$ is a pLB141 derivative where the $\mathrm{P}_{\text {nisA }}$ promoter region has been replaced by $\mathrm{P}_{\mathrm{Zn}} z i t R$ to control the expression of exp4 $4_{S P^{-}} n u c$ (encoding $\mathrm{SP}_{\operatorname{Exp} 4}-\mathrm{Nuc}$ ). The unique NsiI restriction site allows cloning of any open reading frame as a translational fusion to $\mathrm{SP}_{\text {Exp } 4} \cdot \mathbf{b}$ Coomassie brilliant blue staining analysis. IL1403 (pLB145) strain was grown on GM17 medium at

\section{Conclusions}

L. lactis is an attractive host to produce and secrete heterologous proteins. To further promote its biotechnological use, we are developing a toolbox comprising an expression/secretion system and a set of improved host strains. A tightly regulated expression system $\left(\mathrm{P}_{\mathrm{Zn}} z i t R\right)$ was combined in 1 vector with a consensus secretion signal $\left(\mathrm{SP}_{\text {Exp4 }}\right)$ and used in a mutant strain (htrA) that assures protein stability at the cell surface. B. subtilis SecDF accessory protein might also be used in the case of problematic recombinant proteins. In the future, several tools reported to enhance protein secretion and production should be combined into a single strain. Our system is compatible with large-scale production processes and downstream purification steps should be simple and thus low cost. $30^{\circ} \mathrm{C}$ until $\mathrm{OD}_{600}=0.1\left(\mathrm{~T}_{0}\right)$. At $\mathrm{T}_{0}$, EDTA was added to a final concentration of $1 \mathrm{mM}$. Supernatant samples were taken at $\mathrm{T}_{0}$ and after $1,3,4$ or $5 \mathrm{~h}$ of induction, precipitated and loaded on SDSPAGE. The background smear results from medium peptones precipitation. Major proteins in the medium are indicated by arrows: lactococcal Usp45 protein and the staphylococcal Nuc forms, NucB and NucA (primary and secondary mature forms of $\mathrm{SP}_{\text {Exp4} 4}$-Nuc, respectively).

\section{Acknowledgments}

E.M. is the recipient of a CIFRE grant from the Agence Nationale de la Recherche (France) and GTP Technology (Labège, France). Special thanks are given to S.M. Madsen and A. Vrang from Bioneer A/S (Hørsholm, Denmark) for providing the MG1363 $\Delta$ htrA mutant strain and for contributing to the study of heterologous protein stability in htrA mutant strains. We are grateful to S. Nouaille and Y. Le Loir from INRA for their contributions to the improvement of heterologous protein production and secretion in L. lactis. Thanks to H. Ginisty, N. Issaly and E. Devic from GTP Technology who constantly supported this work. We thank all our colleagues from UBLO or UEPSD at INRA and from GTP Technology for constructive discussions and technical support, and Alexandra Gruss from UBLO for critical reading of the manuscript. 


\section{References}

Bermudez-Humaran LG, Langella P, Commissaire J, Gilbert S, Le Loir Y, L'Haridon R, Corthier G: Controlled intra- or extracellular production of staphylococcal nuclease and ovine omega interferon in Lactococcus lactis. FEMS Microbiol Lett 2003a;224:307313.

-Bermudez-Humaran LG, Langella P, CortesPerez NG, Gruss A, Tamez-Guerra RS, Oliveira SC, Saucedo-Cardenas O, Montes de Oca-Luna R, Le Loir Y: Intranasal immunization with recombinant Lactococcus lactis secreting murine interleukin-12 enhances antigen-specific Th1 cytokine production. Infect Immun 2003b;71:1887-1896.

- Bolhuis A, Broekhuizen CP, Sorokin A, van Roosmalen ML, Venema G, Bron S, Quax WJ, van Dijl JM: SecDF of Bacillus subtilis, a molecular Siamese twin required for the efficient secretion of proteins. J Biol Chem 1998;273:21217-21224.

- Bolhuis A, Tjalsma H, Smith HE, de Jong A, Meima R, Venema G, Bron S, van Dijl JM: Evaluation of bottlenecks in the late stages of protein secretion in Bacillus subtilis. Appl Environ Microbiol 1999;65:2934-2941.

Bolotin A, Wincker P, Mauger S, Jaillon O, Malarme K, Weissenbach J, Ehrlich SD, Sorokin A: The complete genome sequence of the lactic acid bacterium Lactococcus lactis ssp. lactis IL1403. Genome Res 2001;11:731-753.

Bredmose L, Madsen SM, Vrang A, Ravn P, Johnsen MG, Glenting J, Israelsen H: Development of a heterologous gene expression system for use in Lactococcus lactis: a novel Gram-positive expression system; in Merten O-W, Mattanovich D, Lang C, Larsson G, Neubauer P, Porro D, Postma P, Teixeira de Mattos J, Cole JA (eds): Recombinant Protein Production with Prokaryotic and Eukaryotic Cells - A Comparative View on Host Physiology. Dordrecht, Kluwer Academic Publishers, 2001, pp 270-272.

- Brurberg MB, Haandrikman AJ, Leenhouts KJ, Venema G, Nes IF: Expression of a chitinase gene from Serratia marcescens in Lactococcus lactis and Lactobacillus plantarum. Appl Microbiol Biotechnol 1994;42:108-115.

-Callegari ML, Riboli B, Sanders JW, Cocconcelli PS, Kok J, Venema G, Morelli L: The S-layer gene of Lactobacillus helveticus CNRZ 892: cloning, sequence and heterologous expression. Microbiology 1998;144:719-726.

- Cortes-Perez NG, Poquet I, Oliveira M, Gratadoux JJ, Madsen SM, Miyoshi A, Corthier G, Azevedo V, Langella P, Bermúdez-Humarán LG: Construction and characterization of a Lactococcus lactis strain deficient in intracellular ClpP and extracellular HtrA proteases. Microbiology 2006;152:2611-2618. de Ruyter PG, Kuipers OP, Beerthuyzen MM, van Alen-Boerrigter I, de Vos WM: Functional analysis of promoters in the nisin gene cluster of Lactococcus lactis. J Bacteriol 1996; 178:3434-3439.

de Vos WM: Gene expression systems for lactic acid bacteria. Curr Opin Microbiol 2:289295.

de Vos WM, Kleerebezem M, Kuipers OP: Expression systems for industrial Gram-positive bacteria with low guanine and cytosine content. Curr Opin Biotechnol 1997;8:547553.

Dieye Y, Hoekman AJ, Clier F, Juillard V, Boot HJ, Piard JC: Ability of Lactococcus lactis to export viral capsid antigens: a crucial step for development of live vaccines. Appl Environ Microbiol 2003;69:7281-7288.

Dieye Y, Usai S, Clier F, Gruss A, Piard JC: Design of a protein-targeting system for lactic acid bacteria. J Bacteriol 2001;183:41574166.

Drouault S, Anba J, Bonneau S, Bolotin A, Ehrlich SD, Renault P: The peptidyl-prolyl isomerase motif is lacking in PmpA, the PrsA-like protein involved in the secretion machinery of Lactococcus lactis. Appl Environ Microbiol 2002;68:3932-3942.

Drouault S, Corthier G, Ehrlich SD, Renault P: Expression of the Staphylococcus hyicus lipase in Lactococcus lactis. Appl Environ Microbiol 2000;66:588-598.

Foucaud-Scheunemann C, Poquet I: HtrA is a key factor in the response to specific stress conditions in Lactococcus lactis. FEMS Microbiol Lett 2003;224:53-59.

Franz CM, van Belkum MJ, Worobo RW, Vederas JC, Stiles ME: Characterization of the genetic locus responsible for production and immunity of carnobacteriocin A: the immunity gene confers cross-protection to enterocin B. Microbiology 2000;146:621-631.

-Gaeng S, Scherer S, Neve H, Loessner MJ: Gene cloning and expression and secretion of Listeria monocytogenes bacteriophage-lytic enzymes in Lactococcus lactis. Appl Environ Microbiol 2000;66:2951-2958.

Hyyryläinen HL, Sarvas M, Kontinen VP: Transcriptome analysis of the secretion stress response of Bacillus subtilis. Appl Microbiol Biotechnol 2005;67:389-396.

Israelsen H, Madsen SM, Vrang A, Hansen EB, Johansen E: Cloning and partial characterization of regulated promoters from Lactococcus lactis Tn917-lacZ integrants with the new promoter probe vector, pAK80. Appl Environ Microbiol 1995;61:2540-2547.

Jana S, Deb JK: Strategies for efficient production of heterologous proteins in Escherichia coli. Appl Microbiol Biotechnol 2005;67: 289-298.

- Jensen PR, Hammer K: Minimal requirements for exponential growth of Lactococcus lactis. Appl Environ Microbiol 1993;59:43634366.
Kontinen VP, Saris P, Sarvas M: A gene (prsA) of Bacillus subtilis involved in a novel, late stage of protein export. Mol Microbiol 1991;5: 1273-1283.

Kontinen VP, Sarvas M: The PrsA lipoprotein is essential for protein secretion in Bacillus subtilis and sets a limit for high-level secretion. Mol Microbiol 1993;8:727-737.

Kuipers OP, de Ruyter PG, Kleerebezem M, de Vos WM: Controlled overproduction of proteins by lactic acid bacteria. Trends Biotechnol 1997;15:135-140.

Kuipers OP, de Ruyter PG, Kleerebezem M, de Vos WM: Quorum sensing-controlled gene expression in lactic acid bacteria J Biotechnol 1998;64:15-21

-Kuipers OP, Rollema HS, Siezen RJ, de Vos WM: Lactococcal expression systems for protein engineering of nisin. Dev Biol Stand 1995;85: 605-613.

Kunji ER, Slotboom DJ, Poolman B: Lactococcus lactis as host for overproduction of functional membrane proteins. Biochim Biophys Acta 2003;1610:97-108

- Le Loir Y, Azevedo V, Oliveira SC, Freitas DA, Miyoshi A, Bermudez-Humaran LG, Nouaille S, Ribeiro LA, Leclercq S, Gabriel JE, Guimaraes VD, Oliveira MN, Charlier C, Gautier M, Langella P: Protein secretion in Lactococcus lactis: an efficient way to increase the overall heterologous protein production. Microb Cell Fact 2005;4:2.

Le Loir Y, Gruss A, Ehrlich SD, Langella P: A nine-residue synthetic propeptide enhances secretion efficiency of heterologous proteins in Lactococcus lactis. J Bacteriol 1998; 180: 1895-1903.

Le Loir Y, Nouaille S, Commissaire J, Bretigny L, Gruss A, Langella P: Signal peptide and propeptide optimization for heterologous protein secretion in Lactococcus lactis. Appl Environ Microbiol 2001;67:4119-4127.

Li W, Zhou X, Lu P: Bottlenecks in the expression and secretion of heterologous proteins in Bacillus subtilis. Res Microbiol 2004;155: 605-610.

Llull D, Poquet I: New expression system tightly controlled by zinc availability in Lactococcus lactis. Appl Environ Microbiol 2004;70: 5398-5406.

-Madsen SM, Arnau J, Vrang A, Givskov M, Israelsen $\mathrm{H}$ : Molecular characterization of the $\mathrm{pH}$-inducible and growth phase-dependent promoter P170 of Lactococcus lactis. Mol Microbiol 1999;32:75-87.

- Madsen SM, Hindre T, Le Pennec JP, Israelsen H, Dufour A: Two acid-inducible promoters from Lactococcus lactis require the cis-acting $\mathrm{ACiD}-\mathrm{box}$ and the transcription regulator RcfB. Mol Microbiol 2005;56:735-746.

Madsen SM, Vrang A, Arnau J, Ravn P, Johnsen MG, Israelsen $\mathrm{H}$ : Lactic acid bacterial regulatable expression system. Patent US 6133023. 2000. 
Malten M, Nahrstedt H, Meinhardt F, Jahn D: Coexpression of the type I signal peptidase gene sipM increases recombinant protein production and export in Bacillus megaterium MS941. Biotechnol Bioeng 2005;91:616-621.

-Martinez JM, Kok J, Sanders JW, Hernandez PE: Heterologous coproduction of enterocin A and pediocin PA-1 by Lactococcus lactis: detection by specific peptide-directed antibodies. Appl Environ Microbiol 2000;66:35433549.

Mierau I, Kleerebezem M: 10 years of the nisincontrolled gene expression system (NICE) in Lactococcus lactis. Appl Microbiol Biotechnol 2005;68:705-717.

-Mierau I, Leij P, van Swam I, Blommestein B, Floris E, Mond J, Smid EJ: Industrial-scale production and purification of a heterologous protein in Lactococcus lactis using the nisin-controlled gene expression system NICE: the case of lysostaphin. Microb Cell Fact 2005a;4:15.

Mierau I, Olieman K, Mond J, Smid EJ: Optimization of the Lactococcus lactis nisin-controlled gene expression system NICE for industrial applications. Microb Cell Fact 2005b;4:16

-Miyoshi A, Jamet E, Commissaire J, Renault P, Langella P, Azevedo V: A xylose-inducible expression system for Lactococcus lactis. FEMS Microbiol Lett 2004;239:205-212.

-Miyoshi A, Poquet I, Azevedo V, Commissaire J, Bermudez-Humaran L, Domakova E, Le Loir Y, Oliveira SC, Gruss A, Langella P. Controlled production of stable heterologous proteins in Lactococcus lactis. Appl Environ Microbiol 2002;68:3141-3146.

-Nouaille S, Commissaire J, Gratadoux JJ, Ravn P, Bolotin A, Gruss A, Le Loir Y, Langella P: Influence of lipoteichoic acid D-alanylation on protein secretion in Lactococcus lactis as revealed by random mutagenesis. Appl Environ Microbiol 2004;70:1600-1607.

- Nouaille S, Morello E, Cortes-Peres N, Le Loir Y, Commissaire J, Gratadoux JJ, Poumerol E, Gruss A, Langella P: Complementation of the Lactococcus lactis secretion machinery with Bacillus subtilis SecDF improves secretion of staphylococcal nuclease. Appl Environ Microbiol 2006;72:2272-2279.

- Novotny R, Scheberl A, Giry-Laterriere M, Messner P, Schaffer C: Gene cloning, functional expression and secretion of the S-layer protein SgsE from Geobacillus stearothermophilus NRS 2004/3a in Lactococcus lactis. FEMS Microbiol Lett 2005;242:27-35.
Perez-Martinez G, Kok J, Venema G, van Dijl JM, Smith $\mathrm{H}$, Bron S: Protein export elements from Lactococcus lactis. Mol Gen Genet 1992;234:401-411.

Piard JC, Jimenez-Diaz R, Fischetti VA, Ehrlich SD, Gruss A: The M6 protein of Streptococcus pyogenes and its potential as a tool to anchor biologically active molecules at the surface of lactic acid bacteria. Adv Exp Med Biol 1997;418:545-550.

- Poquet I, Bolotin A, Gruss A: Optimisation de la production de protéines hétérologues exportées chez Lactococcus lactis par inactivation de HtrA, son unique protéase de ménage de surface. Lait 2001;81:1-11.

Poquet I, Bolotin A, Sorokin A, Gruss A: Grampositive bacteria deprived of HtrA proteasic activity, and their uses. Patent US6994997 B1. 2006.

Poquet I, Ehrlich SD, Gruss A: An export-specific reporter designed for Gram-positive bacteria: application to Lactococcus lactis. J Bacteriol 1998;180:1904-1912.

Poquet I, Llull D: Zinc-regulated prokaryotic expression cassettes. Patent application US2006199246. 2006.

- Poquet I, Saint V, Seznec E, Simoes N, Bolotin A, Gruss A: HtrA is the unique surface housekeeping protease in Lactococcus lactis and is required for natural protein processing. Mol Microbiol 2000;35:1042-1051.

Que YA, Francois P, Haefliger JA, Entenza JM, Vaudaux P, Moreillon P: Reassessing the role of Staphylococcus aureus clumping factor and fibronectin-binding protein by expression in Lactococcus lactis. Infect Immun 2001;69:6296-6302.

-Que YA, Haefliger JA, Francioli P, Moreillon P: Expression of Staphylococcus aureus clumping factor $\mathrm{A}$ in Lactococcus lactis subsp. cremoris using a new shuttle vector. Infect Immun 2000;68:3516-3522.

-Ravn P, Arnau J, Madsen SM, Vrang A, Israelsen $\mathrm{H}$ : The development of TnNuc and its use for the isolation of novel secretion signals in Lactococcus lactis. Gene 2000;242:347-356.

- Ravn P, Arnau J, Madsen SM, Vrang A, Israelsen H: Optimization of signal peptide SP310 for heterologous protein production in Lactococcus lactis. Microbiology 2003;149:21932201.

Riesenberg D, Guthke R: High-cell-density cultivation of microorganisms. Appl Microbiol Biotechnol 1999;51:422-430.
Rigoulay C, Entenza JM, Halpern D, Widmer E, Moreillon P, Poquet I, Gruss A: Comparative analysis of the roles of HtrA-like surface proteases in two virulent Staphylococcus aureus strains. Infect Immun 2005;73:563-572.

-Sarvas M, Harwood CR, Bron S, van Dijl JM: Post-translocational folding of secretory proteins in Gram-positive bacteria. Biochim Biophys Acta 2004;1694:311-327.

- Sibakov M, Koivula T, von Wright A, Palva I: Secretion of TEM $\beta$-lactamase with signal sequences isolated from the chromosome of Lactococcus lactis subsp. lactis. Appl Environ Microbiol 1991;57:341-348.

Tjalsma H, Antelmann H, Jongbloed JD, Braun PG, Darmon E, Dorenbos R, Dubois JY, Westers H, Zanen G, Quax WJ, Kuipers OP, Bron S, Hecker M, van Dijl JM: Proteomics of protein secretion by Bacillus subtilis: separating the 'secrets' of the secretome. Microbiol Mol Biol Rev 2004;68:207-233.

van Asseldonk M, de Vos WM, Simons G: Functional analysis of the Lactococcus lactis Usp45 secretion signal in the secretion of a homologous proteinase and a heterologous $\alpha$-amylase. Mol Gen Genet 1993;240:428434

van de Guchte M, Kodde J, van der Vossen JM, Kok J, Venema G: Heterologous gene expression in Lactococcus lactis subsp. lactis: synthesis, secretion, and processing of the Bacillus subtilis neutral protease. Appl Environ Microbiol 1990;56:2606-2611.

van der Vossen JM, van der Lelie D, Venema G: Isolation and characterization of Streptococcus cremoris Wg2-specific promoters. Appl Environ Microbiol 1987;53:2452-2457.

-Wei W, Xiang H, Tan H: Food-grade expression of human $\mathrm{Cu} / \mathrm{Zn}$-superoxide dismutase gene in Lactococcus lactis. Wei Sheng Wu Xue Bao 2003;43:347-353.

-Westers L, Westers H, Quax WJ: Bacillus subtilis as cell factory for pharmaceutical proteins: a biotechnological approach to optimize the host organism. Biochim Biophys Acta 2004; 1694:299-310.

Wu SC, Wong SL: Engineering of a Bacillus subtilis strain with adjustable levels of intracellular biotin for secretory production of functional streptavidin. Appl Environ Microbiol 2002;68:1102-1108.

Xiang H, Liu J, Hu W, Zhu J, Zhu Z: Expression in Lactococcus lactis of catalytically active phenylalanine ammonia-lyase from parsley. Wei Sheng Wu Xue Bao 1999;39:196-204. 